\title{
Toward positive and systemic mental health practices in schools: Fostering social-emotional learning through service
}

Mental health services in schools in the $21^{\text {st }}$ century will be prevention-oriented with a grounding in positive psychology and strong school-family-community partnerships that emphasize proactive and systemic practices to build social-emotional competencies for all children. This article makes the case for youth development through service learning to promote social and emotional wellness.

KEY WORDS

service learning; partnerships; positive psychology; youth development; mental health

ORgANizATIONS - College of Education and Human Development, University of Massachusetts Boston, Boston, USA AUthors' Contribution - A: Study design · B: Data collection · C: Statistical analysis · D: Data interpretation .

E: Manuscript preparation · F: Literature search · G: Funds collection

CORRESPONDing AUthor - Prof. Felicia Wilczenski, College of Education and Human Development,

University of Massachusetts Boston, 100 Morrissey Blvd., Boston, MA 02125-3393, tel. 617-287-7592,

e-mail: Felicia.Wilczenski@umb.edu

TO CITE THIS ARTICLE - Wilczenski, F. L., \& Cook A. L. (2014). Toward positive and systemic mental health practices

in schools: fostering social-emotional learning through service. Health Psychology Report, 2(3).

DOI: $10.5114 /$ hpr.2014.44425 
As the $21^{\text {st }}$ century began, Seligman and Csikszentmihalyi (2000), advocated for a change in perspective among mental health professionals from a pathology orientation to positive psychology, emphasizing social and emotional wellness. This new branch of psychology seeks scientific understanding and effective interventions to build healthy individuals, families, and communities instead of solely treating mental illness. Positive psychology emphasizes prevention and focuses on enhancing positive traits rather than correcting deficiencies. This shift to positive psychology opposes the traditional emphasis on disability-seeking diagnostic activities and remedial interventions prevalent in schools.

Students are often referred for psychological services because of behavior problems that may not be associated with psychopathology. Larson (2000) noted that boredom, alienation, school disengagement, and disconnection from meaningful purpose in life among youth are not signs of mental illness in most cases, but rather signs of a deficiency in positive development. Damon (1995) discussed the social effects of purposelessness that may include deviant and destructive behavior, lack of productivity, and an inability to maintain interpersonal relationships as well as the emotional effects that may include self-absorption, depression, psychosomatic complaints, and possibly addiction. On the positive side, purpose during youth can lead to desirable outcomes, such as prosocial behavior, moral commitment, academic achievement, and high self-esteem (Billig, 2004, 2011; Leyba, 2010). Finding purpose in life is essential for the positive mental health development of youth.

\section{TRANSFORMING MENTAL HEALTH SERVICES}

How can schools develop climates to foster purpose and positive mental health? To accomplish the change from a deficit to asset model of practice, social and emotional learning must be viewed as a legitimate educational aim for all students and integrated with the academic mission of schools (Durlak, Weissberg, Dymnicki, Taylor, \& Schelinger, 2011; Sklad, Diekstra, DeRitter, Ben, \& Gravestein, 2012; Weissberg \& Cascarino, 2013). The shift to a positive paradigm coincides with efforts in the United States to transform school-based mental health services from individual to systemic models (Adelman \& Taylor, 1999, 2000, 2001, 2005; Dahir \& Stone, 2013). That is, practitioners who provide mental health services in schools no longer work solely with individual students but also incorporate parents and families into the process (e.g., through engaging in collaboration and implementation of behavioral plans that are implemented in the home [Dougherty, 2009; Grothaus \& Cole, 2010; Kampwirth, 2012]). In addition, they may consult with teachers, administrators, and other staff in developing and implementing mental health and academic-related interventions (Clemens, 2007; Kampwirth, 2012; Parsons \& Kahn 2005).

Mental health services in schools need to extend beyond individual counseling to incorporate programs that promote social-emotional learning, foster resiliency, address school disengagement, enhance academic achievement, and make connections with the community. Emerging trends in mental health services involve strengthening schools, families, and communities to optimize student learning (Adelman \& Taylor, 1999, 2000; Epstein \& Van Voorhis, 2010) as well as college and career readiness (Dymnicki, Sambolt, \& Kidron, 2013). Meeting students' social-emotional and academic needs can be best achieved when schools partner with families and community members (Bryan \& Henry, 2012; Bryan \& Griffin, 2010). Research in school-family-community partnerships emphasizes the importance of including a variety of stakeholders to support youth's development, including social-emotional development, academic outcomes, and college and career trajectories (Bailey \& Bradbury-Bailey, 2010; Bryan \& Henry, 2012; Grothaus \& Cole, 2010; Harkavy \& Hartley, 2009; Henderson \& Mapp, 2002). Steen and Noguera (2010) suggested the need for "an integrated approach that moves beyond merely implementing in-school interventions to involve all school stakeholders" (p. 45). While school-based counselors have significant expertise and knowledge in collaborating with parents and families (in addition to providing direct services to students), they may not regularly engage with community members as a means of promoting students' social-emotional and academic learning. One way to enhance youth's development in these areas is through providing students the opportunity to engage in service learning within the school community. In fact, Peterson and Seligman (2004) recommended service learning as a deliberate intervention to promote positive social-emotional outcomes. Through providing students opportunities for service learning, school-based mental health professionals can facilitate the necessary community connections that can help to support youth's social-emotional development and positive academic outcomes.

\section{THE CASE FOR SOCIAL, EMOTIONAL, AND SERVICE LEARNING}

Social and emotional learning is defined as the process by which students learn to manage emotions, care about others, behave responsibly, and maintain positive interpersonal relationships (Collaborative for Academic, Social, and Emotional Learning [CASEL], 2003; Elias et al., 1997). As an inclusive pedagogy, service learning can play an important role in 
promoting social as well as emotional development (Fredericks, 2003; Wilczenski \& Cook, 2009). Most service-learning projects are multi-faceted and activities can be arranged to accommodate students with different ability levels and special needs. Data have indicated positive impacts of service on social behavior, emotional adjustment, acceptance of diversity, ethical development, resiliency, academic achievement (Billig, 2004, 2011; Fredericks, 2003; Schaffer, Berman, Pickeral, \& Homan, 2001), self-esteem, friendships, and confidence (Leyba, 2010). The beneficial effects of service learning also extend to children and adolescents typically referred for mental health services, such as students with disabilities and those with behavioral and academic problems (Brigman \& Molina, 1999; Kraft \& Wheeler, 2003; Muscott, 2000; Piliavin, 2003; Shoultz, Miller, \& Ness, 2001). When service-learning experiences are linked to the school curriculum, students engaging in community-based service learning have been more likely to make positive academic gains (Chiaravalloti, 2009). Moreover, engaging in service learning in ways that promote youth activism (i.e., promoting a sense of responsibility of citizenship) may also help promote resiliency and positive social-emotional development among youth at risk for engaging in violent and antisocial behaviors (McKay, 2010).

Social and emotional competencies are best developed in real life situations with opportunities for practice and feedback (Cohen, 2001). Through service-learning experiences within authentic community contexts, students gain a sense of purpose in affecting their environment (Damon, Menon, \& Bronk, 2003). As a positive, asset-based pedagogy, service learning incorporates all the essential components of comprehensive school-based mental health services identified by Adelman and Taylor (2005):

- To promote social-emotional development and resiliency;

- To intervene early after the onset of mental health problems;

- To increase the capacity of all school staff to promote mental health;

- To address systemic matters that affect mental health, such as bullying and disengagement, and

- To rely on evidence-based practices in developing school and community interventions to foster positive development.

These components are common to high quality service-learning programs. Through service, students experience real world opportunities for social and emotional learning (Russell \& Hutzel, 2007).

Service learning is curriculum-based. It ties community service to academic and/or social-emotional learning goals. Performing service is a form of experiential education where learning occurs through cycles of action and reflection as students work with others to solve a community problem while reflect- ing upon their experiences to gain a deeper understanding of themselves. Reflection turns service into learning.

The most widely accepted definition of service learning is based upon the National and Community Service Act of 1990, and includes the following four dimensions:

- Students learn through participation in organized experiences that meet actual community needs and are coordinated with school and community;

- The program is integrated into the academic curriculum with time to process and reflect upon those experiences;

- Students are given opportunities to use their knowledge and skills in real-life situations in communities; and

- Learning is extended beyond the classroom into the community, which fosters the development of a sense of caring.

Traditional mental health practices in schools are frequently decontextualized and center on counseling or other interventions for individual students. Mental health initiatives are frequently seen as secondary to that for which schools are held accountable, that is, academic achievement. Yet, substantial evidence indicates the opposite - social and emotional competence enables academic learning (Zins, Weissberg, Wang, \& Walberg, 2004), and typically interventions targeting academic achievement have been effective when they incorporate interventions focusing on social-emotional development (Bailey \& Bradbury-Bailey, 2010, Chenoweth, 2007). For example, Zychinski and Polo (2012) examined the relationship between depressive symptoms and academic achievement among Latino students and found that development of academic self-efficacy helped to lower depressive symptoms. Based on their findings, they identified the importance of focusing on academic experiences when providing treatment for depression in school settings. Thus, when providing mental health services to youth, it behooves school-based counseling professionals to implement interventions that are systemic (i.e., they include collaboration with families, communities, teachers, and other school staff) and comprehensive (i.e., they incorporate issues related to social-emotional development, contextual factors, and academics).

\section{SERVICE-LEARNING CASE EXAMPLES}

Service learning can serve as a bridge to connect work of school-based mental health professionals and educators. Instead of having students with social and emotional difficulties served by others, those students can be included in service-learning projects as service providers. For example, as an alternative to conducting groups focused on anger management,
Positive and systemic practices in schools 
service-learning opportunities could be arranged to teach empathy, social skills, and emotional regulation while addressing academic goals at the same time. Elias, Zins, Graczyk, and Weissberg (2003) described a service-learning alternative to an anger management program that was focused on deficits and remediation. Virtually the same activities that were addressed in an anger management group, which the children resisted, were taught in the context of a Newspaper Club - listening, interacting with others, negotiating calmly, problem solving, in which the children participated enthusiastically. The students served the school and community by keeping them informed of current events through their newspaper. It is easy to see the potential ties to academic standards in terms of writing skills, social studies, and math.

Wilczenski and Cook (2009) reported another case study: Service learning was employed as an intervention for eight $6^{\text {th }}$-grade middle school students at risk for academic failure due to social and emotional adjustment difficulties. They were placed in small group special education resource rooms for academic instruction. Teachers and administrators labeled the students as "behavior problems". Data showed that this group of students averaged three discipline referrals per week to the principal's office. Because of these referrals, instructional time was significantly reduced. A service-learning program was initiated with all $6^{\text {th }}$ grade students in which students focused their attention on various school good deed projects to benefit the school community, including playground clean-up, recycling bottles and cans, and decorating bulletin boards. These "good deeds" were ideas generated by students to improve school appearance, to be a part of the academic curriculum, and not a punishment for inappropriate behavior. The counselor and teacher collaborated to integrate academic lessons with the service projects. In math class, for example, the students calculated the cost of paying a janitor for clean-up activities. Writing assignments included research papers on environmental issues and the importance of recycling. The eight students labeled as "behavior problems" were given the responsibility as leaders for collaborative teams of students on the service-learning projects. These 8 students also took the lead in planning holiday decorations for the main office.

After three months time, the number of discipline referrals for the eight students dropped to a total of three, down from the previous average of three per week. For the entire class, attendance increased, tardiness decreased, and the students reported that they liked school much better. By participating in this service-learning project, these so-labeled "behavior problem" students became much more motivated toward and felt more included in the life of the school in a meaningful way. The project certainly can be said to have given these students a "purpose" for school. Also evident is the connection of academics with real life skills and situations. It is a wonderful illustration of simultaneously addressing the social and emotional needs of students while teaching academic skills.

This service-learning project was an authentic one that conveyed a sense of purpose in helping with a real need in the school community. Acting as helpers and leaders was an especially important aspect of this project because the eight students in special education who were involved in this service learning were often not trusted with responsibility. Rather than focusing on the students' social and emotional deficits, service learning involved them in a task with so many dimensions that it became easy to find ways to include them with their regular class and capitalize on their strengths.

Similarly, Leyba (2010) identified positive outcomes of employing service-learning opportunities within students' school building, including the development of increased self-esteem, confidence, and friendships. Some of the service learning activities youth engaged in consisted of helping younger students, helping adults (such as assisting staff members with office tasks), providing leadership and mentorship through peer clubs and group interventions, performing school functions (including raising the school flag, acting as line leader, and picking up attendance lists), decorating hallways and common areas, and coordinated special events and school-based projects (assisting with drama performances and serving as volunteers during special school-based events).

Consider the following example of communitybased service learning for a student with autism spectrum disorder (ASD): The defining characteristics of ASD are impairments of social communication and interaction, along with restricted and repetitive activities and interests. Making and maintaining friendships proves difficult for students with ASD. Joseph is a 16-year-old student with autism spectrum disorder (ASD). He has age appropriate math skills, but is several years below grade level in reading and writing. He is interested in computers and is relatively skilled using electronics. Joseph does not have close friends at school and spends most of his free time alone playing computer games. His parents do not encourage him to socialize with peers because they afraid he will be teased by them. Joseph needs opportunities to develop positive work behaviors, practice appropriate social skills, and develop marketable job skills. He was included a service project to address social and emotional learning. Joseph joined a group of other $10^{\text {th }}$ grade high school students who visited a community senior center to help the members learn to use email and access the Internet. This project was suited to his technology strengths and interests and provided social opportunities to inter- 
act with his peers as well as older adults. Through this service, Joseph was able to contribute to his community while practicing interpersonal skills and emotional regulation.

\section{SERVICE LEARNING IN MENTAL HEALTH PROFESSIONAL TRAINING}

Service learning has empirical support as a high impact educational practice in colleges and universities (Kuh, 2008), with positive effects on students' personal and social development (Simons \& Cleary, 2006). The key element of service-learning programs is the opportunity students have to both apply their learning in real-world settings and reflect in a classroom setting on their service experiences (Simons \& Cleary, 2006). These programs also convey the idea that giving back to the community is an important college outcome, and that working with community partners is good preparation for citizenship and employment.

A number of mental health training programs have incorporated service learning in their degree requirements. Graduate students learn about service as a positively oriented intervention and then experience service learning in their course work. References to service-learning applications in graduate training for mental health professionals can be found in school psychology (e.g., Wilczenski, Coomey, \& Ball, 2004), counseling (e.g., Arman \& Scherer, 2002; Perkins \& Brumfield, 2009), and social work (e.g., Kropf \& Tracey, 2002). The website of the American School Counselor Association has links to service-learning resources (see: http://www.schoolcounselor.org/ search.aspx?searchtext=service\%20learning\&searchmode=anyword). Service learning also is employed as an approach to teaching and learning in psychology (Bringle \& Duffy, 1998). The American Psychological Association (APA) now regularly holds sessions on applications of service learning at its conferences and has information about service learning on its website (see: http://www.apa.org/search.aspx?query =service $\% 20$ learning).

Service learning in graduate education can augment programs of study in fundamental ways relevant to the values, ethics, and attitudes that are the basis of professional mental health practices. Experience with service learning during their professional preparation can lead mental health practitioners to a deeper intellectual interest and understanding of the nature of helping relationships. The unique training experiences available to students through service-learning activities address wellness promotion and home/school/community collaboration. Furthermore, multicultural education for mental health counselors centers on learning about cultural diversity, addressing disability issues, examining power relationships and inequality, and responding in a positive manner to socio-cultural differences in schools and communities. One of the most consistent outcomes of service learning is the reduction of negative stereotypes and an increase in the tolerance for diversity (Eyler \& Giles, 1999).

\section{CONCLUSIONS}

Service learning promotes social-emotional and academic development through active engagement in community activities (e.g., Leyba, 2010; Russell \& Hutzel, 2007; Simons \& Cleary, 2006). It challenges students to think beyond themselves and to develop empathy in service to others. In today's economic climate, resources may be limited to support individual counseling in schools. Service learning is a costeffective preventative strategy to support mental health while fostering academic development. Projections about mental health services in schools in the $21^{\text {st }}$ century suggest they will be prevention-oriented with a grounding in positive psychology and strong school-family-community partnerships that emphasize proactive and systemic practices to build social-emotional competencies for all children.

\section{References}

Adelman, H. S., \& Taylor, L. (1999). Reframing mental health in schools and expanding school reform. Educational Psychologist, 33, 135-152. DOI: 10.1207/s15326985ep3304_1

Adelman, H. S., \& Taylor, L. (2000). Moving prevention from the fringes into the fabric of school improvement. Journal of Educational and Psychological Consultation, 11, 7-36.

Adelman, H. S., \& Taylor, L. (2001). Framing new directions of school counselors, psychologists, and social workers. Los Angeles, CA: Center for Mental Health in Schools.

Adelman, H. S., \& Taylor, L. (2005). Mental health in urban schools. Los Angeles, CA: Center for Mental Health in Schools.

Arman, J. F., \& Scherer, D. (2002). Service-learning in school counselor preparation: A qualitative analysis. Journal of Humanistic Counseling, Education, and Development, 41, 69-86. DOI: 10.1002/j.2164490X.2002.tb00131.x

Bailey, D. F., \& Bradbury-Bailey, M. E. (2010). Empowered youth programs: Partnerships for enhancing postsecondary outcomes of African American adolescents. Professional School Counseling, 14, 64-74.

Billig, S. H. (2004). Heads, hearts, and hands: The research on K-12 service-learning. In: J. Kielsmeier, M. Neal, \& M. McKinnon (eds.). Growing to
Positive and systemic practices in schools 
greatness: The state of service-learning project (pp. 12-25). St. Paul, MN: National Youth Leadership Council.

Billig, S. H. (2011). Why service learning is such a good idea. Colleagues, 5, 9-11.

Brigman, G., \& Molina, B. (1999). Developing social interest and enhancing school success skills: A service-learning approach. Journal of Individual Psychology, 55, 342-354.

Bringle, R. G., \& Duffy, D. (eds.). (1998). With service in mind: Concepts and models for service-learning in psychology. Washington, DC: American Association for Higher Education.

L. Wilczenski, Amy L. Cook

Bryan, J. A., \& Griffin, D. (2010). A multidimensional study of school-family-community partnership involvement: School, school counselor, and training factors. Professional School Counseling, 14, 75-86.

Bryan, J., \& Henry, L. (2012). A model for building school-family-community partnerships: Principles and process. Journal of Counseling and Development, 90, 408-420. DOI: 10.1002/j.1556-6676.20 12.00052.x

Chenoweth, K. (2007). It's being done: Academic success in unexpected schools. Cambridge, MA: Harvard Education Press.

Chiaravalloti, L. A. (2009). Making the switch: Lightbulbs, literacy, and service-learning. Voices from the Middle, 17, 24-33.

Clemens, E. (2007). Developmental Counseling and Therapy as a Model for School Counselor Consultation with Teachers. Professional School Counseling, 10, 352-359.

Cohen, J. (ed.). (2001). Caring classrooms/intelligent schools: The social emotional education of young children. New York: Teachers College Press.

Collaborative for Academic, Social, and Emotional Learning. (2003). Safe and sound: An educational leader's guide to evidence-based social and emotional learning programs. Chicago, IL: University of Illinois.

Dahir, C., \& Stone, C. B. (2013). The transformed school counselor ( $2^{\text {nd }}$ ed.). Belmont, CA: Brooks/ Cole; Cengage Learning.

Damon, W. (1995). Greater expectations: Overcoming the culture of indulgence in our homes and schools. New York: Free Press.

Damon, W., Menon, J., \& Bronk, K. C. (2003). The development of purpose during adolescence. Applied Developmental Science, 7, 119-128. DOI: 10.1207/S1532480XADS0703_2

Dougherty, A. M. (2009). A Casebook of Psychological Consultation and Collaboration in School and Community Settings ( $5^{\text {th }}$ ed.). Belmont, CA: Cengage Brooks/Cole.

Durlak, J. A., Weissberg, R. P., Dymnicki, A. B., Taylor, R. D., \& Schelinger, K. (2011). The impact of enhancing students' social and emotional learning: A meta-analysis of school-based universal in- terventions. Child Development, 82, 405-432. DOI: 10.1111/j.1467-8624.2010.01564.x

Dymnicki, A., Sambolt, M., \& Kidron, Y. (2013, March). Improving college and career readiness by incorporating social and emotional learning. Washington, DC: College and Career Readiness \& Success Center at the American Institutes for Research.

Elias, M. J., Zins, J. E., Graczyk, P. A., \& Weissberg, R. P. (2003). Implementation, sustainability, and scaling up of social-emotional and academic innovations in public schools. School Psychology Review, 12, 303-319.

Elias, M. J., Zins, J. E., Weissberg, R. P., Frey, K., Greenberg, M., Haynes, N., \& Shriver, T. P. (1997). Promoting social and emotional learning: Guidelines for educators. Alexandria, VA: Association for Supervision and Curriculum.

Epstein, J. L., \& Van Voorhis, F. L. (2010). School counselors' roles in developing partnerships with families and communities for student success. Professional School Counseling, 14, 1-14.

Eyler, J., \& Giles, D. E. (1999). Where's the learning in service-learning? San Francisco, CA: Jossey-Bass.

Fredericks, L. (2003). Making the case for social and emotional learning and service learning. Chicago, Philadelphia, and Denver: Collaborative of Academic, Social, and Emotional Learning: Mid-Atlantic Regional Educational Laboratory for Students Success. Education Commission of the States.

Grothaus, T., \& Cole, R. (2010). Meeting the challenges together: School counselors collaborating with students and families with low income. Journal of School Counseling, 8. Retrieved from: http://files. eric.ed.gov/fulltext/EJ895909.pdf

Harkavy, I. \& Hartley, M. (2009). Universityschool-community partnerships for youth development and democratic renewal. New Directions for Youth Development, 122, 7-18. DOI: 10.1002/ yd.303

Henderson, A. T., \& Mapp, K. L. (eds.). (2002). A new wave of evidence: The impact of school, family, and community connections on student achievement. Austin, TX: National Center for Family and Community Connections with Schools, Southwest Educational Development Laboratory. Retrieved from http://www.sedl.org/connections/ research-syntheses.html

Kampwirth, T. J. (2012). Collaborative consultation in the schools $\left(4^{\text {th }}\right.$ ed.). Upper Saddle River, NJ: Merrill Prentice Hall.

Kraft, N., \& Wheeler, J. (2003). Service-learning and resilience in disaffected youth: A research study. In: S. H. Billig \& J. Eyler (eds.). Deconstructing service-learning: Research exploring context, participation, and impacts (pp. 213-238). Greenwich, CT: Information Age Publishing. 
Kropf, N. P., \& Tracey, M. (2002). Service-learning as a transition into foundation field placements. $A d-$ vances in Social Work, 3, 60-71.

Kuh, G. D. (2008). High impact educational practices: What they are, who has access to them, and why they matter. Washington, DC: Association of American Colleges and Universities.

Larson, R. W. (2000). Toward a psychology of positive youth development. American Psychologist, 55, 170-183. DOI: 10.1037/0003-066X.55.1.170

Leyba, E. (2010). How school social workers integrate service opportunities into multiple elements of practice. Children \& Schools, 32, 27-49. DOI: 10.1093/cs/32.1.27

McKay, C. (2010). Critical service learning: A school social work intervention. Children \& Schools, 32, 5-13. DOI: $10.1093 / \mathrm{cs} / 32.1 .5$

Muscott, H. S. (2000). A review and analysis of service-learning programs involving students with behavioral disorders. Education and Treatment of Children, 23, 346-368.

National and Community Service Act. (1990). Pub. L. No. 101-610.

Parsons, R. D., \& Kahn, W. J. (2005). The school counselor as consultant: An integrated model for school-based consultation. Belmont, CA: Thomson Brooks/Cole.

Perkins, G., \& Brumfield, K. (2009). Service learning in counselor education programs: Combating truancy. In: G. R. Walz, J. C. Bleuer, \& R. K. Yep (eds.). Compelling counseling interventions. VISTAS 2009 (pp. 185-189). Alexandria, VA: American Counseling Association.

Peterson, C., \& Seligman, M. E. P. (2004). Character strengths and virtues: A handbook and classification. NY: Oxford University Press and Washington, DC: American Psychological Association.

Piliavin, J. A. (2003). Doing well by doing good: Benefits for the benefactor. In: C. L. M. Keyes \& J. Haidt (eds.). Flourishing: Positive psychology and the life well-lived (pp. 227-247). Washington, DC: American Psychological Association.

Russell, R. L., \& Hutzel, K. (2007). Promoting social and emotional learning through service-learning art projects. Art Education, 60, 6-11.

Schaffer, E., Berman, S., Pickeral, T., \& Holman, E. (2001). Service learning and character education: One plus one is more than two. Denver, CO: Education Commission of the States.

Seligman, M. E. P., \& Csikszentmihalyi, M. (2000). Positive psychology: An introduction. [Special issue]. American Psychologist, 55. DOI: 10.1037/0003066X.55.1.5

Shoultz, B., Miller, E. E., \& Ness, J. (2001). Volunteerism by persons with developmental disabilities [Special Issue]. Impact, 14.

Simons, L., \& Cleary, B. (2006). The influence of service learning on students' personal and social development. College Teaching, 54, 307-319. DOI: 10.3200/CTCH.54.4.307-319

Sklad, M., Diekstra, R., DeRitter, M., Ben, J., \& Gravestein, C. (2012). Effectiveness of school-based universal social, emotional, and behavioral programs: Do they enhance students' development in the area of skill, behavior and adjustment. Psychology in the Schools, 49, 892-909. DOI: 10.1002/ pits. 21641

Steen, S., \& Noguera, P. S. (2010). A broader and bolder approach to school reform: Expanded partnership roles for school counselors. Professional School Counseling, 14, 42-52.

Weissberg, R. P., \& Cascarino, J. (2013). Academic learning + social and emotional learning = national priority. Phi Delta Kappan, 95, 8-13.

Wilczenski, F. L., \& Cook, A. L. (2009). How service learning addresses the mental health needs of students in urban schools. Journal of School Counseling, 7. Retrieved from http://www.jsc.montana. edu/articles/v7n25.pdf

Wilczenski, F. L., Coomey, S. M., \& Ball, B. A. (2004). Service-learning as a vehicle for educating school psychologists. School Psychology Trainers' Forum, 23, 1-6, 8.

Zins, J. E., Weissberg, R. P., Wang, M. C., \& Walberg, H. J. (eds.). (2004). Building academic success on social emotional learning. New York: Teachers College Press.

Zychinski, K. E., \& Polo, A. J. (2012). Academic achievement and depressive symptoms in low-income Latino youth. Journal of Child and Family Studies, 21, 565-577. DOI: 10.1007/s10826-011-9509-5
Positive and systemic practices in schools 